\title{
Product Strategy: \\ Factors That Influence Product Strategy Decisions Of SMEs In South Africa
}

\author{
Michael C. Cant, University of South Africa, South Africa \\ Professor Johannes A. Wiid, University of South Africa, South Africa \\ Ms Safura Mohamed Kallier, University of South Africa, South Africa
}

\begin{abstract}
Deciding on the right products to offer to the market is a demanding and crucial task that requires understanding and insight into the customer's needs and wants. This task is even more important and crucial for SME's who in many instances have to rely on the knowledge and feeling of the owner/manager only to make these decisions. It is therefore important for SME's to have a well thought out strategy when deciding on what products to sell. This study aimed to identify factors related to products that SMEs consider when selecting products to sell. Surveys were sent out to SME's around South Africa. The results indicated that SME's selected products based on the quality of the product and customer demand.
\end{abstract}

Keywords: SME's; South Africa; Product; Strategies; Quality; Product Life-Cycle

\section{INTRODUCTION}

E elling the right product, to the right customers is what makes a business successful. A product is defined as a tangible or non- tangible good or service that is offered to the customer in exchange for some unit of value (Cant \& van Heerden 2013: 164). The aim of the product is to satisfy the needs of the customer as a result of the direct use of the product (Cant \& van Heerden 2013: 164). From a marketing perspective the product includes the features and attributes that are associated with the product and enhances the consumer's experience of the product. Each product goes through a life cycle, after which it must be either replaced or re-invented (The economic times 2014). The product lifecycle maps out the life span of the product and at each stage different product decisions and marketing tools are used to promote the product. The business identifies a strategy at each stage of the product lifecycle that will enhance the product to the consumer (Chandrasekar 2010: 8).

Small to medium sized enterprises (SME's) are considered to be the backbone of any economy as they play a major role in the economic development of a country (Ayanda \& Laraba, 2011: 200). The market environment in which SME's operate in is however harsh and constantly changing. SME's must thus ensure that their product offering will keep customers interested and coming back. The products that the SME offers to their target market are essential to the business as without the right products, the business will not make a profit. From the selection of the product, right through the various stages of its life cycle, the business will have to make certain strategic decisions. Product decisions in SMEs differ considerably compared to larger organisations and this study aims to identify if SMEs develop strategies when deciding on products to sell and if so what factors do SME owners consider when deciding on what products to sell in their businesses.

\section{LITERATURE REVIEW}

Small business enterprises (SME's) are essential to any developing economy as they assist in the growth of the economy and the creation of employment opportunities in a country (Cant 2011:1107). In South Africa, SME's account for about half of the private Gross Domestic Product (GDP) of the country (Mutanda, De Beer \& Myers 
2014:153). SME's contributes to the economy at a social level as well, through ensuring the distribution of income, supporting monetary stability and encouraging innovation (Gomes, Moshkovich \& Torres 2010: 21).

Even though SME's play a huge role in the growth of the economy of a country, they have a high failure rate. Studies show that $40 \%$ of new businesses fail within their first year and $60 \%$ fail by their second year of operation (Cant 2012:1108). These failures are caused by factors such as changing economic climate of a country, competition and lack of demand for a product and lack of variety of products, lack of quality products and a lack of strategic planning (Cant \& Wiid 2013: 708, Ebersole, 2014).

Developing product strategies provide alternative options for the business depending on the market conditions. Product decisions and strategies in SMEs are developed differently compared to larger organisations. SMEs have fewer resources at their disposal, a limited amount of individuals to make strategic decisions and a smaller budget for marketing activities (Gomes et al., 2010: 21). Strategic decisions regarding products in SMEs are made mostly by the owner of the business and are usually based on the opinions of the owner (Gomes et al., 2010: 21). Decisions are more informal and the focus is on the short term, whereas decision making in big businesses are formal and are usually guided by a model (Gomes, et al., 2010: 22).

Previous research has focused on business and marketing strategies in SME's and on product innovation. Sharma (2011) found that SME's needed to develop and implement strategies to survive the tough competitive business environment. A study conducted by Hagen, Zucchella, Cerchiello \& DeGovanni (2011) concluded that firms that have a clear strategy are able to peruse international opportunities, expand successfully and grow. Leitner \& Guldenberg (2009) aimed to identify the impact of generic strategies on the performance of SME's. Their study found that firms that followed a cost efficiency or differentiation strategy performed equally well. They further found that firms that followed a combination strategy performed equally or even greater than firms following cost efficiency or differentiation strategy. It is evident that there is a lack of research regarding strategies used by SME's when selecting products to sell.

\subsection{Selecting the right products}

Selecting the right products to sell is critical for any business as the business is defined by the products that they sell (Rodriguez 2014).The products that the business sells must fulfil some need or satisfy a want for the consumer (Ramsey \& Ramsey 2010: 132). It is thus important to know and understand the customers' needs and wants when selecting the products for the business. It is also important to consider the life-cycle of the product in relation to the type of customers the business is targeting. Consumers who are trendsetters and innovators will most likely be interested in the latest products whereas consumers who are late adopters will prefer to purchase a product only after their peers have recommended it (Edmund 2014).

Competition should also be considered when making a decision on the products to sell. The business must determine who their competitors are, how similar their products are to the businesses products and what unique features does their products have (Rodriguez 2014). It is also important to consider the price of the product to be sold. Products that are priced low will provide high sales volumes, while products that are high priced will result in low sales volumes but higher gross profits (Edmund 2014). When considering the price of the product, it is important to take into account the brand image and position of the business in the market (Edmund 2014).

Decisions regarding the selection of products for a business to sell are important for a business and could influence the success or failure of the business. This article thus aims to identify if SMEs make use of strategies when selecting products to sell, and the various product factors that they consider when deciding on products to sell.

The next section will discuss the research objectives, methodology and findings of the research. 


\section{RESEARCH OBJECTIVES}

This study aims to determine whether SMEs develop product strategies in their businesses and if so what strategies do they consider when selecting products to sell. The study further aims to determine what product factors do SME's consider when deciding on products to sell.

\subsection{METHODOLOGY AND FINDINGS}

To determine whether SME's develop product strategies, and if so, what strategies, a sample of small business owners were asked to quantitatively rate how important they perceive different product factors to be when they select products to sell in their business. The questionnaire was administered to various business owners within South Africa and a total of 105 usable responses were received. Most of the respondents were female (58.62\%) with more than half who are older than $40(56.9 \%)$. A large portion of the respondents were owners of their business (79\%), some of which are also managers of their businesses. The SME sector that these businesses operated in consisted mainly of construction (20\%), business services (10\%), manufacturing (10\%) and retail (7.1\%). A large proportion of the respondents' businesses have existed for less than five years $(60.8 \%)$ while one quarter of the respondents' businesses have existed for six to ten years $(25.7 \%$,). Almost half of the respondents $(41.8 \%)$ reported that their annual turnover is less than R100000.

The small business owners were presented with a set of ctcts that could influence their choice in deciding what products to sell. The respondents were requested to rate the importance of each factor when they considered a specific product and if they would sell that product in their stores.

The research findings will be discussed below.

\subsection{Research Findings}

Small business owners were presented with a set of eight factors regarding products that they could use to guide their selection of products to sell. They were asked to rate the importance of each factor on a five point scale that ranged from not important to extremely important.

Table 1: Importance Ratings Of Product Factors

\begin{tabular}{|c|c|c|c|c|c|c|c|}
\hline & $\begin{array}{c}\text { Not } \\
\text { Important (n) }\end{array}$ & $\begin{array}{c}\text { Slightly } \\
\text { Important (n) }\end{array}$ & $\begin{array}{c}\text { Important } \\
(\mathbf{n})\end{array}$ & $\begin{array}{c}\text { Very } \\
\text { Important (n) }\end{array}$ & $\begin{array}{c}\text { Extremely } \\
\text { Important (n) }\end{array}$ & Total N & Mean (SD) \\
\hline Quality & $0.0 \%(0)$ & $1.0 \%(1)$ & $5.9 \%(6)$ & $18.6 \%(19)$ & $74.5 \%(76)$ & 102 & $3.67(.635)$ \\
\hline Benefits & $2.0 \%(2)$ & $1.0 \%(1)$ & $16.0 \%(16)$ & $32.0 \%(32)$ & $49.0 \%(49)$ & 100 & $3.25(.903)$ \\
\hline Popularity & $1.0 \%(1)$ & $2.1 \%(2)$ & $20.8 \%(20)$ & $31.3 \%(30)$ & $44.8 \%(43)$ & 96 & $3.17(.902)$ \\
\hline Customer demand & $0.0 \%(0)$ & $0.0 \%(0)$ & $8.2 \%(8)$ & $30.9 \%(30)$ & $60.8 \%(59)$ & 97 & $3.53(.647)$ \\
\hline Price of the product & $1.0 \%(1)$ & $3.0 \%(3)$ & $19.0 \%(19)$ & $30.0 \%(30)$ & $47.0 \%(47)$ & 100 & $3.19(.918)$ \\
\hline Competition & $1.0 \%(1)$ & $2.1 \%(2)$ & $23.2 \%(22)$ & $30.5 \%(29)$ & $43.2 \%(41)$ & 95 & $3.13(.914)$ \\
\hline Brand name & $1.0 \%(1)$ & $3.1 \%(3)$ & $16.3 \%(16)$ & $29.6 \%(29)$ & $50.0 \%(49)$ & 98 & $3.24(.909)$ \\
\hline Sale rights & $2.1 \%(2)$ & $3.1 \%(3)$ & $27.8 \%(27)$ & $26.8 \%(26)$ & $40.2 \%(39)$ & 97 & $3.00(1.00)$ \\
\hline
\end{tabular}




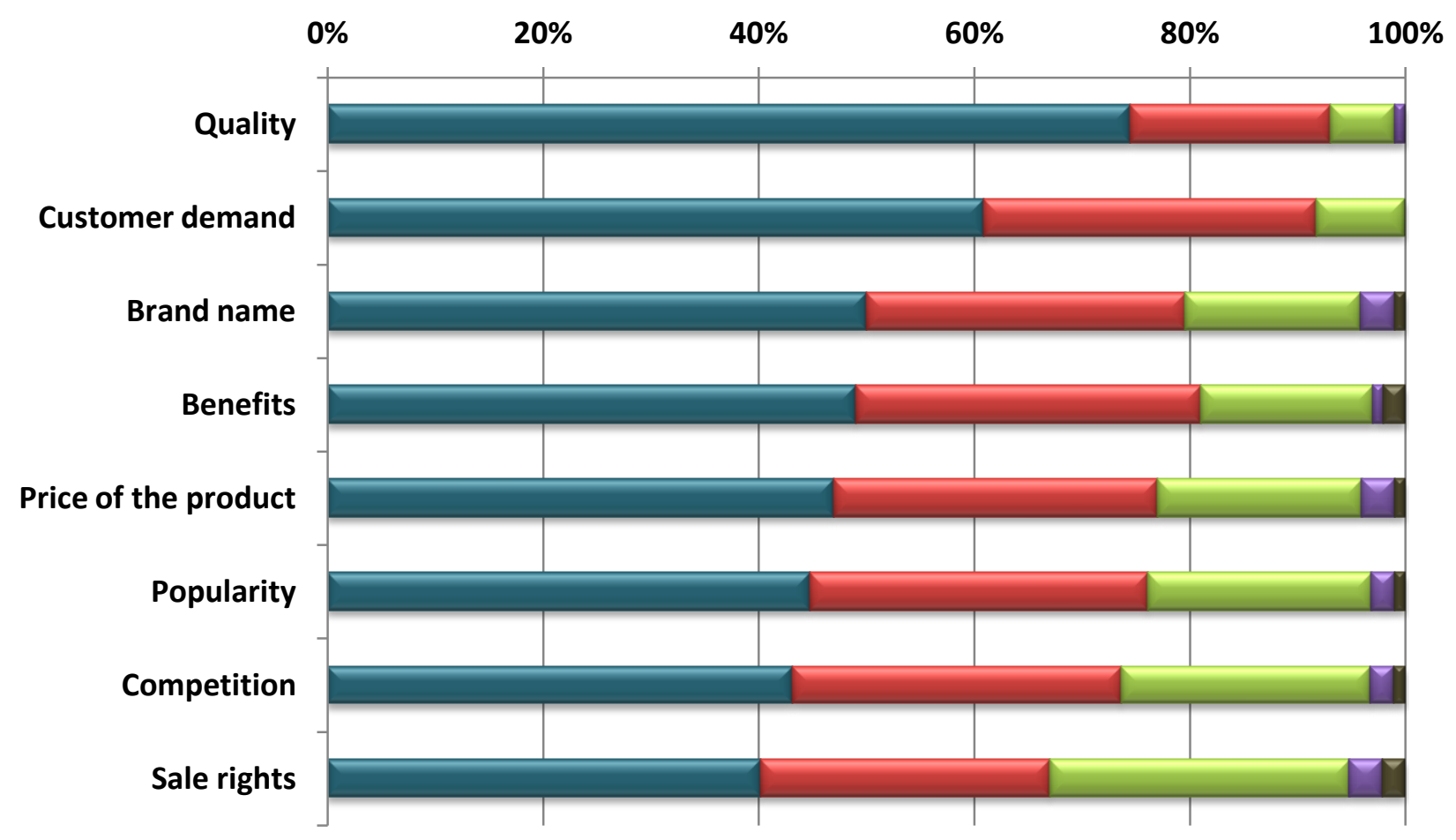

$\square$ Extremely important $\square$ Very important $\square$ Important $\square$ Slightly important $\square$ Not Important

Figure 1: Importance Ratings Of Product Factors

From Figure 1and Table 1 it can be seen that product quality is the most important factor that is considered when choosing products to sell with $93.1 \%$ of the respondents having rated it as either Very important (18.6\%) or Extremely important (74.5\%). This importance is confirmed by the mean importance rating (3.67) being the highest and the standard deviation (.635), an indication of variation in importance ratings, being the lowest. The second most important factor is Customer demand with $81.0 \%$ of the respondents having rated it as either Very important (32.0\%) or Extremely important $(49.0 \%)$, also confirmed by the mean importance rating (3.53) being the second highest, accompanied by the second smallest variation (.647) among importance ratings. On average, Brand name (3.24) and Benefits (3.25) are equally important in third place.

Although there is a clear ranking in perceived importance of the eight product factors involved in selecting products to sell, all mean values are above the middle value (2) of the scale it was measured on $(0=$ Not important to $4=$ (Extremely important), indicating that all factors are considered important. This is also demonstrated by the fact that Quality and Customer demand was not rated Not important by any of the respondents while the other factors were rated Not Important by only one (Popularity, Price, Competition, Brand name) or two (Benefits, Sale rights) respondents. 


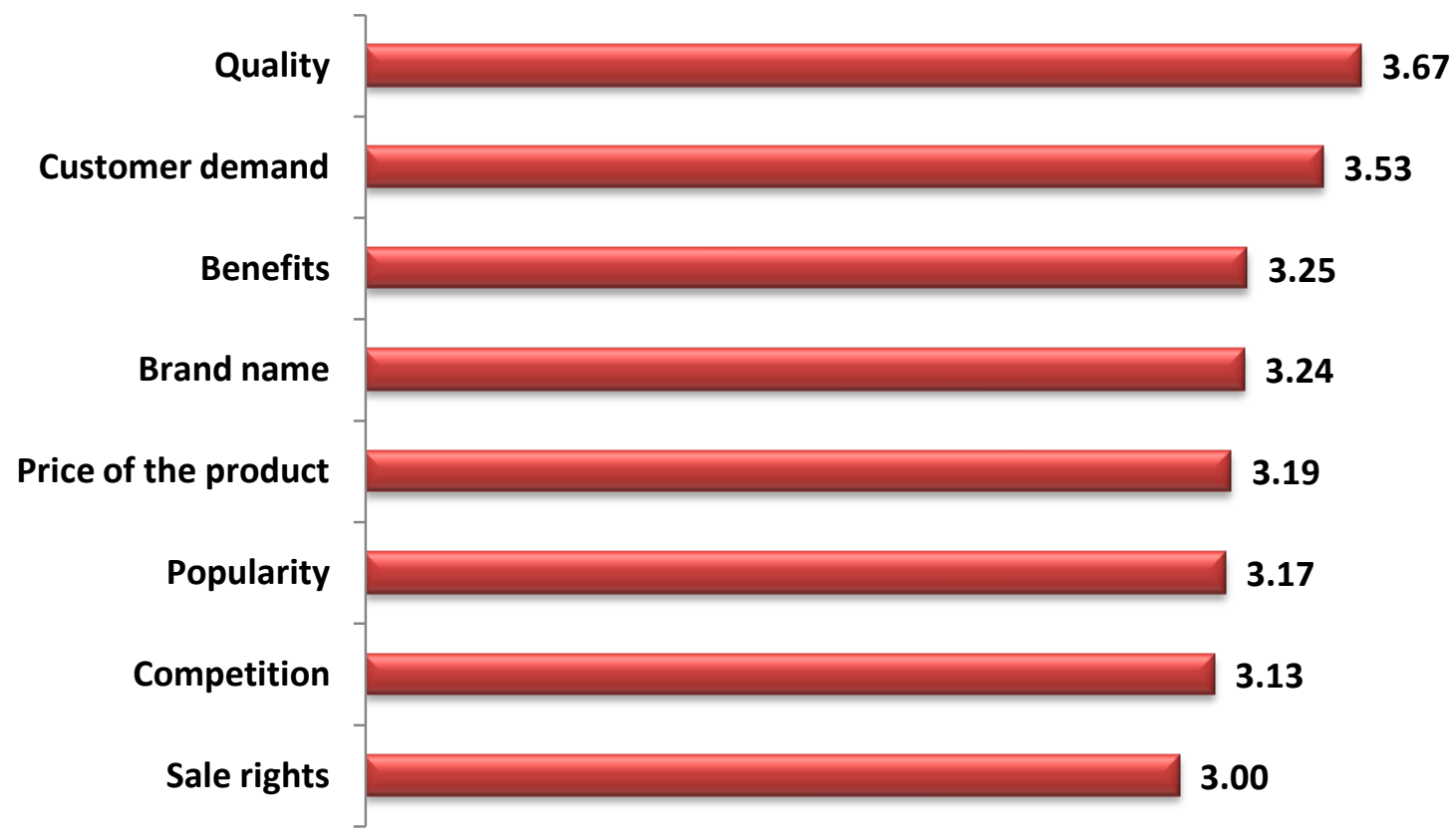

Figure 2: Mean Importance Of Product Factors

\subsubsection{Cluster Analysis}

To establish whether there are distinct patterns among the respondents regarding how important they rated the various product factors that may be relevant when deciding which products to sell, the eight factor items were subjected to K-means cluster analysis.

Four different groups were distinguished, indicating that respondents do have different opinions regarding which product factors they consider important when deciding which range of products to offer. The cluster centre values of the separate groups are listed in Table 3 and how the distinguishing features differ per group is depicted in Figure 3.

Table 3: Final Cluster Centers

\begin{tabular}{lccccc}
\hline & Mavericks & Connoisseurs & Laissez-faire group & Conformists & Overall Mean \\
\hline Quality & 3.625 & 4.000 & 3.500 & 3.320 & 3.65 \\
Benefits & 3.125 & 3.970 & 2.955 & 2.480 & 3.55 \\
Popularity & 3.375 & 3.879 & 3.364 & 2.920 & 3.26 \\
Customer demand & 3.875 & 3.939 & 3.000 & 3.400 & 3.24 \\
Price of the product & 1.875 & 3.818 & 3.000 & 3.200 & 3.22 \\
Competition & 1.750 & 3.848 & 2.455 & 3.160 & 3.18 \\
Brand name & 3.625 & 3.909 & 2.227 & 3.120 & 3.11 \\
Sale rights & 2.250 & 3.788 & 1.909 & 3.200 & 3.01 \\
\hline
\end{tabular}




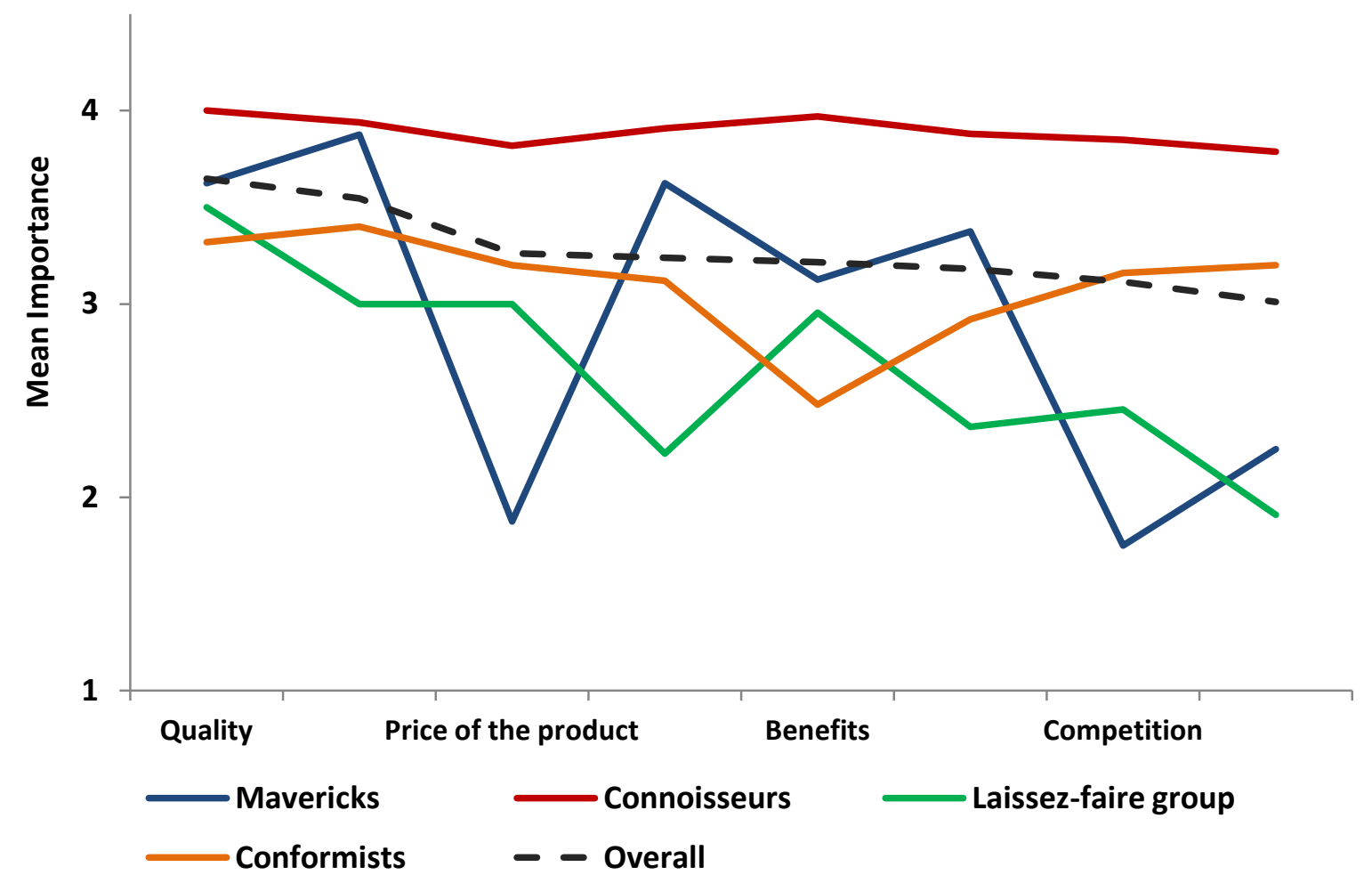

Figure 3: Cluster Groups

\subsubsection{Description of Clusters}

On average, the respondents as a single group (overall) rated quality, customer demand and brand name as the most important factors to consider when selecting products to sell.

The Mavericks (these respondents had strong opinion differences) had the largest variation in their importance rating across the different product attributes, displaying strong opinion differences among the factors. They tended to consider three of the factors, quality, customer demand, and brand name, as very important and to a lesser extent they tended to consider popularity and benefits as important when selecting products to sell. This group echoed the quality, customer demand and brand name ratings of the group as a whole although the importance of customer demand and brand name is more pronounced. The importance rating of price, competition and sale rights on the other hand is much lower than that of the group as a whole. This group's product strategy focused on what the customer wanted and what was important to them and thus followed a customer focused strategy when selecting products to sell.

The Connoisseurs judge all of the product factors to be very important when deciding which products to sell and rated them all above the overall average importance. This group focuses mainly on generating sales and consider all factors that will result in achieving maximum profits. These SMEs thus followed a sales orientated strategy when deciding on what products to sell.

The Laissez-faire group (these respondents were more lax in their choices) rate all of the product factors as less important than the overall average, with quality being the only factor that they rated as more than just important when selecting products to sell. Customer demand and price are only just important to them while popularity, competition, brand name and sale right seem not to be considered when selecting a product range. The strategy for this group focused more on the quality of the product when deciding on what products to sell. 
The Conformists (these respondents confirmed to the trends) tended to follow the overall average importance for all factors except quality, benefits and popularity which they rated below the overall average importance. For them, benefits are the least important. This group focused more on external factors of the product such as the price, the brand name of the product and competition rather than internal factors such as quality.

The only product factor for which all groups are in relative agreement on is quality.

Table 4: Distribution Of Respondents Among The Four Cluster Groups

\begin{tabular}{llcc}
\hline & N & Percent \\
\hline \multirow{4}{*}{ Valid } & Mavericks & 8 & 9.1 \\
& Connoisseurs & 33 & 37.5 \\
& Laissez-faire group & 22 & 25.0 \\
& Conformists & 25 & 28.4 \\
& Total & 88 & 100.0 \\
\hline
\end{tabular}

\section{$37.5 \%$}

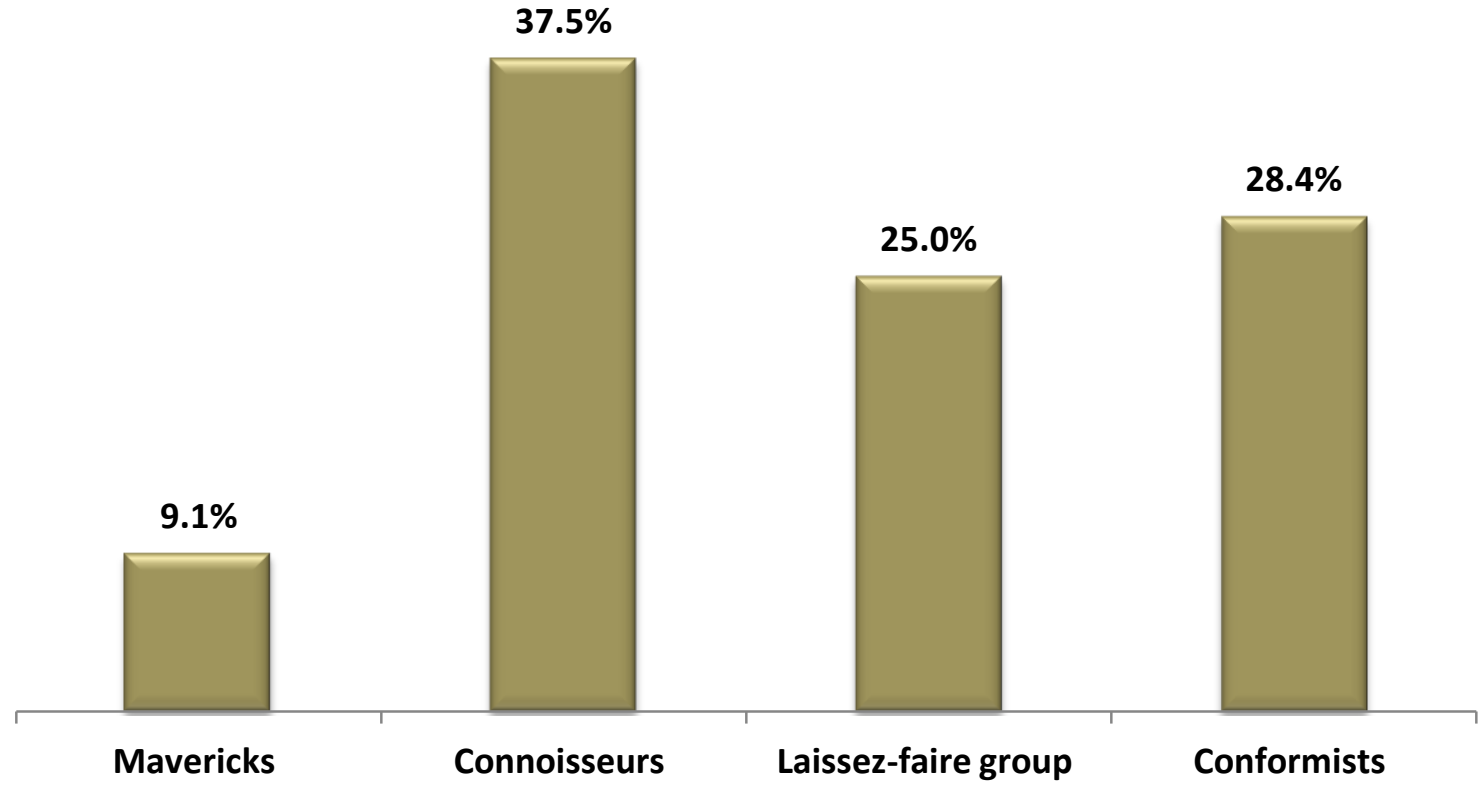

Figure 4: Cluster Groups Distribution

The largest proportion of the respondents are the Connoisseurs (37.5\%, $\mathrm{n}=33$ ), followed by the Conformists $(28.4 \%, \mathrm{n}=25)$, the Laissez-faire group $(25.0 \%, \mathrm{n}=22)$ and the Mavericks $(37.5 \%, \mathrm{n}=33)$.

Judging from the four different patterns of importance ratings of the different product factors among the respondents that were uncovered with cluster analysis, it seems as though the respondents do have varying strategies regarding how they go about selecting products to sell. These groups indicated that the SME's product strategies were either customer focused (Mavericks), sales orientated (Connoisseurs), quality focused (Laissez-faire) or focused on external factors of the product (Conformists).

\section{CONCLUSION}

The aim of any SME should be to satisfy the needs and wants of their customers through their product offering. Therefore selecting the right products to sell is essential as selling the wrong products can result in loss of profit for the SME. It is thus important for the SME to have a strategy when selecting the correct products to sell.

The study aimed to determine if SMEs developed product strategies in their businesses and if so what strategies did they consider. It is clear from the findings that SME's do have product strategies when selecting 
products to sell. This fact could contribute to why some SME's are successful and why others are not. The cluster analysis was done to identify distinct patterns amongst respondents regarding the importance of the various factors. The analysis revealed four strategic groupings that SMEs could possibly fall into when making product decisions. The Maverick group focused on the customer's demands, the Connoisseur group focused on generating sales, the Laissez- faire group focused on the product factors itself and the Conformists group focused on external factors when making decisions on what products to sell.

The study further aimed to determine which factors SMEs consider when deciding on what products to sell. Respondents were asked to rate the importance of various factors that could guide their selection of what products to sell. The study indicated SMEs in South Africa considered quality and customer demand as the most important factors when deciding on a product to sell. SME's also agreed that customers will most likely pay a premium price for brand named products. It is clear from the study that clusters of SME owners can be formed based on various product characteristics.

These findings presented a limited set of factors that could be considered in making product decisions. Future research could build on these findings by possibly extending the sets of factors that could influence the decisions of SME's with regards to selecting the right products to sell, to determine the extent to which the resulting product decision profile groups tend to be successful or not.

\section{AUTHOR INFORMATION}

Professor Michael C. Cant is the COD of the Department of Marketing and Retail Management at the Department of Marketing and Retail Management, University of South Africa (UNISA). Tel: +27 (012) 429 4456, e-mail: cantmc@unisa.ac.za.

Professor Johannes A. Wiid is a professor in Marketing and Research at the Department of Marketing and Retail Management, University of South Africa (UNISA). Tel: +27 (012) 429 3939, e-mail: jwiid@ unisa.ac.za.

Ms Safura M Kallier is a lecturer in Marketing and Retail Management at the Department of Marketing and Retail Management, University of South Africa (UNISA). Tel: +27 (012) 429 3758; e-mail: kallism@ unisa.ac.za.

\section{REFERENCES}

Ayanda, A.M. \& Laraba, A. S. (2011). Small and Medium Scale Enterprises as A Survival Strategy for Employment Generation in Nigeria. Journal of Sustainable Development. 4(1), 200-206.

Cant, M.C. \& Wiid, J. (2013). Establishing the challenges affecting South African SMEs, International business and economics research journal, 12(6), 707-716. Retrieved from http://journals.cluteonline.com/index.php/IBER/article/view/7869/7928 [Accessed: 2014-04-08].

Cant, M.C. (2012) Challenges faced by SME's in South Africa: Are marketing skills needed? International business and economics research journal, 11 (10) 1107-1116.

Can, M.C., \& Van Heerden C.H. (2013). Marketing Management: A South African Perspective, Claremont, Juta \& Company Ltd.

Chandrasekar, K.S. (2010). Marketing Management: text and cases, New Delhi, Tata McGraw Hill.

Ebersole, J.G. 2014. "Twelve causes for small business failures, according to your strategic thinking business coach"[Online] Available from: http://www.evancarmichael.com/Business-Coach/223/Twelve-CausesFor-Small-Business-Failures-According-To-Your-Strategic-Thinking-Business-Coach.html [Accessed: 2014-04-08].

Edmund, S. A. (2014). Product assortment strategy, Retrieved from http://smallbusiness.chron.com/productassortment-strategy-61517.html [Accessed: 2014-04-08].

Gomes, L.F.A.M., Moshkovich, H., \& Torres, D. (2010). Marketing decisions in small businesses: how verbal decision analysis can help. International journal of management decision making, 11(1) 19-36.

Hagen, B., Zucchella, A. \& DeGiovanni, N, (2012), International strategy and performance- clustering strategic types of SMEs. International Business Review, 21(3), 396-382. Retrieved from http://www.sciencedirect.com/science/article/pii/S0969593111000503 [Accessed: 2014-04-08]. 
Leitner, K.H., \& Guldenberg, S. (2009). Generic strategies and firm performance in SMEs: a longitudinal study of Austrian SMEs. Small Businesses Economy. 35, 169-189. Retrieved from http://download.springer.com/static/pdf/74/art\%253A10.1007\%252Fs11187-009-9239-

x.pdf?auth66=1408531757_74ae629c96527a0f06b2ecda15ea9f43\&ext=.pdf [Accessed: 2014-04-08].

Lorette, K. (2014). The importance of marketing for the success of a business. Retrieved from: http://smallbusiness.chron.com/importance-marketing-success-business-589.html [Accessed: 2014-04-08].

Mutanda, M., De Beer, M., \& Myer. T. G. (2014). The Perception of Small and Micro Enterprises in the City of Durban Central Business District (CBD) (Kwazulu- Natal) (KZN) towards Financial Planning. Journal of social science. 5(6), 153-163. Retrieved from http://mcserorg.ervinhatibi.com/journal/index.php/mjss/article/view/2402/2376 [Accessed: 2014-04-08].

Productlifecyclestages.com, (2014), Product lifecycle stages. Retrieved from http://productlifecyclestages.com/ [Accessed: 2014-04-7].

Ramsey, D., \& Ramsey, J. (2010). The everything guide to starting and running a retail store: All you need to know to get started and succeed in your own retail adventure. Avon, Adams Media.

Rodriguez, G. (2014). What to sell: How to select the right products for your business. Retrieved from http://www.powerhomebiz.com/starting-a-business/choosing-a-business/what-to-sell-how-select-the-rightproduct-for-your-business.htm [Accessed: 2014-04-08].

Sharma, G. (2011). Do SME's need to strategize? Business strategy series. 12(4), 186-194. Retrieved from http://www.emeraldinsight.com/doi/pdfplus/10.1108/17515631111155142 [Accessed: 2014-04-08].

Sharma, N. (2013). Marketing strategy on different stages PLC and its marketing implications on FMCH products. International Journal of Marketing, Financial Services \& Management Research. 2 (3), 121-136. Retrieved from http://indianresearchjournals.com/pdf/IJMFSMR/2013/March/12.pdf [Accessed: 2014-04-09].

The Economic Times. (2013). Definition of product. Retrieved from http://economictimes.indiatimes.com/definition/product [Accessed: 2014-04-08]. 


\section{NOTES}

